\title{
The Language of Multiculturalism in South African Soaps and Sitcoms
}

\author{
Ian Barnard \\ California State University, Northridge, USA
}

This paper examines selected episodes from recent South African television sitcoms and soap operas in order to show how current popular culture in South Africa is working alongside political and social institutions to both chronicle the transformation of the country into a multicultural democracy and imaginatively/materially create a New South Africa. Using cultural studies methodology and rhetorical analysis, I first explore the political meanings of popular local soap operas and sitcoms on South African television. Then I demonstrate the development of these programmes' political agendas in the deployment of multilingualism as a rhetorical device. My ultimate goal is not only to argue for the political role of these television shows in South Africa, but also to draw out the implications of particular discourses in these programmes for culture and policy beyond the South African scene. These shows' representations of linguistic fragmentation, cultural hybridity and multiple sites of struggle are enabled through a variety of discursive techniques such as metaphor and language medium as well as historical contextualisation. They suggest models of postcolonial multicultural democracy that counter patriarchal ethnic nationalisms and essentialist demands for linguistic purity.

Keywords: soap operas, South Africa, metaphor, multilingualism, democracy

\section{Introduction: The Politics of Popular Culture}

In her paper on "The Role of South African Television as an Agent of "Truth and Reconciliation"', Dodge (1996: 152) laments the relative popularity of soap operas and sitcoms on recent South African television as compared with news and documentary programmes; she sees the latter as more politicised, more truthful and better able to effect the South African media's mandate to document social history and envisage a new society. Dodge's position is representative of a strain of ideological critique of popular culture that dismisses such cultural production as 'mass deception', and specifically of critics, politicians and intellectuals in South Africa who only recognise overtly 'committed' discourse as engaging with the past and current political crises in the country. My paper responds to the kind of critique articulated by Dodge through an analysis of selected episodes from recent South Africa television sitcoms and soap operas in order to argue that current popular culture in South Africa is working alongside political and social institutions to both chronicle the transformation of the country into a multicultural democracy and imaginatively/materially create a New South Africa.

The first wave of scholarly studies of popular culture in South Africa mostly focused on the role of theatre, music and literary magazines in the anti-apartheid struggle (e.g. Ansell, 2004; David, 2001; Erb, 2000; Horn, 1986; 
Steadman, 1984, 1986, 1988; also the film Amandla!, 2002). The relatively late arrival of television in South Africa (1976), and the racialised economic disparities in the country under apartheid that at first made TV inaccessible to the majority of South Africans have meant that academic treatments of South African television programming are fairly recent (e.g. Currie \& Markovitz, 1993; Dodge, 1996; Flockemann, 2000; Lewis, 2000; Maingard, 1997; Rooome, 1999). Scholarship that does treat television often examines the broader ideological work of television policy, programming, reception and production, or shows an interest in analysing television documentaries as interventions into and/or collusions with hegemonic South African historiography of the past and present. My particular concern is with the soap operas and sitcoms that are the most popular programming on television (at least until reality TV made its mark in the past few years), but that are sometimes pooh-poohed by scholars and critics concerned with more 'serious' objects of study. My own scope in this paper is at once more modest and more ambitious than much of the other work on South African popular culture in that I am not only interested in reading the texts of specific programmes rather than in surveying the ideologies and materialities of their processes of production, but also want to draw out the implications of particular discourses in these programmes for culture and policy beyond the South African scene.

I contend that the work of popular culture in South Africa is taking place in two related rhetorical realms: the first involves the political, textual and linguistic deployment of metaphor; the second revolves around the resonances and questions that are raised as a result of the oral and written use of particular languages (e.g. isiZulu, English, Afrikaans) and language combinations. In the second part of this paper 'Narrativising the Political', following, I explore the political meanings of recent popular local soap operas and sitcoms on South African television. Then in the third part, 'Multilingual Discourses', I argue for the development of these programmes' political agendas in the deployment of multilingualism as a rhetorical device. Together, these theses suggest a range of discursive strategies with which South African culture might critique and contest its apartheid past and imply an innovative model of multiculturalism for the future. This model mirrors official policy in South Africa in eschewing identitarian essentialisms by favouring multilingual hybridity and democratic commitment over linguistic purity and ethnic exclusivity. I do not intend to present a utopian account of past or present South African popular culture; certainly, there are many problems with popular culture in South Africa, and I will touch on some of these. However, my goal is to look at the moments where the texts I examine and the contexts that produce them manifest interesting and productive interstices, and at the reverberations of such interstices for South Africa and for other cultures for which South Africa, itself the conjunction of first and third worlds, has suddenly shifted position in the past 12 years from being a political pariah to representing the model world citizen.

From where I write as a South African in the USA, this analysis seems a particularly timely intervention not only into growing US-ethnocentrism and a reassertion of Christian fundamentalism to bolster US global domination and succour the invasion of Iraq, but also into worldwide fundamentalisms and 
ethnic nationalisms, including those that are demanding increasingly balkanised and ethnically pure sovereign states, those that assume a two-state solution is the only solution to the Israeli-Palestinian conflict, and to reactionary nationalist responses to $9 / 11$ and the 2005 London bombings in the USA and UK, respectively.

South African television's depictions of South African characters and people of different classes, races, sexualities, ages, genders and political persuasions is in marked contrast to, for instance, media in the USA, where TV networks are still under fire for their failure to adequately represent people of colour in prime time, and where inter-racial romantic relationships are almost nonexistent among lead characters on prime-time network programmes of any kind. (This is not to say that television programming in South Africa has completely changed its stripes overnight. There is still considerable criticism of South African television broadcasters' failure to adequately represent the diversity of the population; some independent television networks have even been threatened with suspension for their failure to comply with government regulations regarding adequate representation of people of colour as station anchors.)

My treatment of the particular texts of popular culture described in this paper uses the historical contexts of the shows to analyse their specific rhetorical features, focusing on metaphor, historical and political allusion, and linguistic code. By reading the shows' rather parochial subplots as metaphors, I am not assuming that their creators have necessarily set out with the intention of raising viewers' political consciousnesses; rather, I am acknowledging that these texts are not received by their South African viewers in a social and political vacuum. The languages in which the stories of the soap operas and sitcoms are told and obfuscated, as well as those which they conjure up, can serve to reinforce the stories, to act as counterpoint to them, or even to create new stories. In this sense, language becomes its own plot, and given the historical and continuing worldwide politicisation of issues around language (the links between language identification and claims for ethnic sovereignties, battles over the recognition of languages as official state languages, debates about languages of instruction in education), and the particular connotations of the various South African languages in the context of the history of apartheid, these plots are as much metaphors for South African politics as are the stories they inscribe.

My methodology is unevenly interdisciplinary in the tradition of other work in Cultural Studies, ${ }^{1}$ though it is more textually based than work in Cultural Studies often is, and also is informed by the insights and paradigms of feminist theory, critical race theory, rhetorical theory, literary criticism, popular culture studies and sociolinguistics. Other research in these fields often (1) reads texts 'against the grain' to show how cultural productions that are outwardly reactionary may in fact be received and used in more progressive ways (e.g. Radway, 1984), (2) focuses on practices of subaltern groups to show how they resist dominant ideologies (e.g. Hebdige, 1979) or (3) examines texts symptomatically to discover how they might be seen as embodiments of and commentaries on the individuals and institutions that produce and consume them (e.g. Wood, 1986). The trajectory of the present 
paper is largely in line with the third paradigm, though, as I have suggested above, I also share the interest of those scholars who are dedicated to complicating reductive attacks on popular culture as always and only inscribing hegemonic values and practices. This is part of the task of valuing the critical examination of all kinds of cultural productions and texts (see e.g. hooks, 1994), of recognising the possibility of complexity in all genres and media, of deploying productive juxtapositions of disparate texts, and of rupturing the distinctions between High and Low Art that has been the legacy of Cultural Studies. My work here is politically and strategically driven but also committed to interrogating and multiplying the meanings and possible sites of politics. As the mantra of the journal Cultural Studies puts it, 'Cultural Studies is about theorizing politics and politicizing theory' (Editorial statement).

\section{Narrativising the Political}

\section{Television in the New South Africa}

South African prime-time television sitcoms and soap operas metaphorise the political processes that are marking the country's transition from apartheid, becoming striking political documents in genres usually known for their apolitical insistence. For instance, they document the emotional process and aftermath of the Truth and Reconciliation Commission through their portrayal of inter-racial couples trying - and often failing - to 'reconcile,' or explore the growing clashes and mixes of races and cultures in families, communities and other groupings in the wake of apartheid's demise. Popular television programming in South Africa is progressively shaping the imaginations and expectations of a population struggling to overcome its apartheid past. I will illustrate this assertion using very particular but also tellingly synecdochal moments from two representative but quite different shows, 102 Paradise Complex and Isidingo. My examples are particular in the sense that they are painstakingly selective and come from specific historical moments in the production of post-apartheid South African politics, sociality and culture. But they are also synecdochal because they embody ways of thinking and hoping that can be found - not everywhere and not without counter - in diverse realms of post-apartheid South Africa, with popular culture acting as the avant-garde manifesto or as the post-present documentation of such thoughts and hopes. These particular shows give glimpses of the kinds of projective visions and strategies I discussed above, and it is these visions and strategies that I am interested in foregrounding, rather than in making claims about the specific programmes in and of themselves.

\section{Paradise Complex: Hybrid identities}

102 Paradise Complex is a low-budget sitcom made by and for South African television, set in the home of a mixed-race middle-class family, Ana and Thabiso, and their four (step-)children. Its episodes chronicle the comedic interactions of the family members, and their relationships with their extended families, neighbours and surrounding communities. In the 2003 'Bat Outta 
Hell' episode of 102 Paradise Complex, Ana, a white woman whose life is growing increasingly chaotic, is exhorted by her black son to enlist the assistance of the local Sangoma (medicine woman/traditional healer). The ensuing scene detailing the medicine woman 'throwing the bones' on the white woman's living room floor would have been unimaginable in the 'old' South Africa, but here depicts the bumpy merging of races and cultures in a country that has only recently legalised racial mixing of any kind. Because the apartheid legislation known as the Immorality Act and Mixed Marriages Act prohibited heterosexual sex and marriage between South Africans of different races (as these races were defined and as individuals were racially classified under South African law), 102 Paradise Complex must construct its main characters as only recently coupled in order to present itself as a believable representation of 'ordinary' South African society. Hence the sitcom's premise: the black man (Thabiso) and white woman (Ana) each have two children from their previous endogamous relationships. As this particular episode unfolds, however, the show does much more than merely describe a utopia of interracial harmony: each of the twists and turns in the plot increasingly unsettles essentialist stereotypes and binarised identity as the show works towards creating a truly hybridised South African multiculture, the complexity and intelligence of this project belying the banality of the generic conventions of sitcoms and the unsophisticated production values of this particular sitcom.

The opening shot of the episode shows Thabiso and Ana asleep in their common bed, immediately establishing the mise-en-scène of the hoped-for middle-class multiracial New South Africa (and of the new South African Broadcasting Corporation, to which I will return later). We later see Ana cleaning the house wearing a traditional Sotho hat in order to protect her hair from the bat that has invaded the house. Although this image does little to upset gender stereotypes (women as domestic workers), it quickly - and comically - establishes the racial upsets that characterise the show. A long history of black women as domestic workers in South Africa is here comically usurped in the image of Ana wearing a Sotho hat, and so identifying across racial lines with Thabiso - Thabiso is Sotho. We soon discover that Thabiso is a lawyer, another departure from the expectations of South African history. When the bat is flying around the bedroom, it is Ana who is hysterical about the bad luck it portends, again subverting racial stereotypes (though, again, partly at the expense of entrenching those about gender): she alludes to the conventional binary that positions black superstition against white rationality in South Africa and elsewhere when she shrieks at Thabiso, 'You, of all people, should understand - being black and all.' Thabiso responds in Afrikaans, the language associated primarily with white Afrikaners (and thus with Ana). The episode shows Ana, meanwhile, mothering their black children in a striking reversal of the bitter images of impoverished black nannies caring for spoilt white children that came to characterise many of apartheid's injustices, speaking to them in a mixture of three languages, and bonding, in particular, with her black (step-)daughter, who calls her 'Ma'. As the episode progresses, entrenched racial stereotypes continue to fly out the window: the man who robs the apartment is white (Ana assumes he has come to take care of the bat), while the pest control man is black (he comments on the fact that Ana had not 
asked the white robber for identification upon letting him into the home, indicating that Ana is still not fully transformed as a 'new' South African).

But it is the arrival of the Sangoma that precipitates the show's most pointed racial commentary. The initial cultural hybridisation punctuated by the image of the white woman desperate for advice from the black Sangoma, while the latter accedes to exoticising expectations by waving a traditional 'witch doctor's' wand and groaning incomprehensibly, is further layered by the Sangoma's bilingualism (she switches seamlessly between isiZulu and kugellyEnglish $^{3}$ ) and her questionable tactics: her most passionate exhortations are devoted to divining the lottery numbers that she must play that day. Her Sangoma performance thus not only pokes fun at primitivist white (and black ${ }^{4}$ ) demands for authentic Otherness, and at those who profit by exploiting these demands, but also demonstrates how the dynamics of modernisation, urbanisation, postcolonialism and postmodernism intersect with the confluence and conflict among races in South Africa to develop a dynamic and antifundamentalist subjectivity. The traditional and the postmodern, the old and the new, exist side by side and overlaid on one another, each inflecting rather than negating the other (the Sangoma's concern about the lottery does not mean that the advice she gives to Ana is useless), the sum not merely an accumulation of its parts, but rather a symptom of a radically mobile and hybridised new national and cultural identity. It's not so much that Ana's 'Westernness' is transformed by the Sangoma in Ana's acknowledgement of her superstitiousness but that the fixity of that Westernness is called into question as its superstitiousness is invited to emerge in the meeting with the Sangoma. And the Sangoma is not so much modernised in her meeting with Ana as the dynamism of the Sangoma's role and subjectivity is given full play when 'tradition' is uncoupled from constricting assumptions of stasis and purity. The show's explicit references to race and politics, meanwhile, reflect the general South African population's obsession with both - in the past a mark of conflict and intolerance, but today a sign of the extraordinary degree of sophistication and self-reflexivity around discourses of race in lay South Africa.

102 Paradise Complex's discursive strategies thus work on multiple levels: (1) its depiction of the coming together of a white and black family literally shows the kinds of personal relationships possible in the New South Africa, while simultaneously standing in for larger communal shiftings and mergings in postapartheid South Africa; (2) the show moves past this rhetoric of correspondence to unsettle racial fixedness, not only as a documentation of past and present practices of hybridity, but also as a utopian vision of the future; (3) however, its retrenchment of gender stereotypes functions both as the trace of the past and as the enabler of its work around race. Individual stories represent national history as sitcom becomes a powerful political document.

\section{Isidingo: Truth and reconciliation}

The South African culture of political self-reflexivity has perhaps been most compellingly reflected in the work of South Africa's Truth and Reconciliation Commission (TRC) (1996-2003), and in a recent spate of films, books and 
studies chronicling and cataloguing the impact of the TRC. The TRC, a body charged with hearing testimony from both perpetrators and victims of political violence in apartheid South Africa, and entrusted with the power to grant amnesty to those who gave a full accounting of their crimes, was established by the post-apartheid South African constitution and headed by Archbishop Desmond Tutu with the goal of promoting national reconciliation in the wake of apartheid. ${ }^{5}$ The fictionalised and nonfiction texts that have focused worldwide attention on the TRC have responded not only to the poignancy of its work in South Africa, but also to the possibilities that the TRC offers other societies as a model methodology for engaging with the after-effects of crimes against humanity, civil wars and fractured societies. The TRC has found its way into popular television culture in South Africa, too, though usually in more indirect manifestations.

Isidingo is an immensely popular, long-running (eight years as of this writing), glossier prime-time South African soap opera, set in various locales. Like 102 Paradise Complex, it infuses politics into its narratives as it follows the business, political and personal fortunes of a large group of multiracial characters associated with the gold mine Horizon Deep near Johannesburg, and their lovers, friends and relatives. Characters have included Barker Haines, an entrepreneur and husband of the CEO of the mining company; Vusi Moletsane, the mine geologist; Mariaan van Onselen; and her husband Jack, the Managing Director of Horizon Deep.

Perhaps the most heart-rending subplot in Isidingo treats the inter-racial relationship between Mariaan and Jack, characters who would have been officially classified as, respectively, 'white' and 'coloured' in apartheid South Africa. ${ }^{6}$ As with the Thabiso/Ana relationship in 102 Paradise Complex, the Mariaan/Jack relationship is an overt attempt to prescriptively represent the 'new' South Africa, as well as a recognition of South African reality.

Like 102 Paradise Complex, then, Isidingo metaphorises South African politics in its various plots and subplots. Many of the characters and narratives of Isidingo deal explicitly with issues of race and racism. And, I will argue, like 102 Paradise Complex, Isidingo moves beyond dutiful documentation in order to complicate and even critique orthodox reductions of race and identity. But, in addition, Isidingo offers a corrective to binary conceptualisations of victim and victimiser, good and evil, and as such serves as a critique of 102 Paradise Complex by showing that a revolutionary vision cannot treat individual axes of identity (e.g. gender, race) independently of one another.

In Isidingo, Mariaan and Jack are haunted by the past - their personal pasts, their racial pasts, and, by analogy, past South African history. Their 'different cultures' are seen as impediments to their relationship and Mariaan remains wounded by Jack's infidelity with a coloured woman, Vanessa, convinced that he was attracted to Vanessa because of her race. She seems unable to forgive Jack. Jack, for his part, confesses at a marriage counselling session that 'shared backgrounds' may have been a factor in his attraction to Vanessa. He later apologises to Mariaan and tells her that she has the right to be angry; one day anger will not be necessary, he says; he will just listen and wait. They are hoping for a new future together, but unsure about its feasibility. When Jack discusses his difficulties with Mariaan with Maggie, an ex-colleague, Maggie 
assures him, 'It will get better, I really believe it will - trust me.' Here the difficulties and hopes of Mariaan and Jack's relationship stand for the larger political processes of 'truth and reconciliation' at the same time that the political is personalised and the TRC is made relevant to individual intimate relationships. The analogies between the Jack/Mariaan relationship and the institutionalisation of Truth and Reconciliation as articulated by the TRC are underpinned by Isidingo's explicit talk about political analogies. After Jack accuses Mariaan of picking at scabs by continuing to revisit his relationship with Vanessa, telling her, 'We didn't have to go there', Mariaan responds that he sounds like a politician trying to win votes. She continues, 'I thought you, of all people, should understand the need for atonement'. After expressing his outrage that Mariaan's assumption is based on his colouredness, he asserts, 'If we're going to pursue political analogy, maybe we should be talking about forgiveness'. Mariaan responds that truth (full disclosure) must precede forgiveness.

These questions of atonement, disclosure and forgiveness are the very issues that were most passionately debated when the TRC was set up, and ultimately provided the rationale for its existence, powers and procedures. Its demands for confession, repentance and forgiveness are movingly exemplified in the 'Register of Reconciliation', a website set up by the TRC where 'ordinary' South Africans could fulfil the commission's charge by acknowledging their complicities with and failures to act against apartheid and committing themselves to racial reconciliation. The register is replete with regret by white South Africans, such as this typical statement of repentance:

To all the people of South Africa, thank you for giving me the opportunity to express my sorrow and regret in not doing enough to stop human rights violations in my country. I am guilty and for that I am sorry. Please forgive me, all those I have ever treated with contempt or injustice. I promise to try to treat all people with fairness and equality and where I see injustice I will speak up against it. I promise to contribute to the positive development of South Africa. (Register of Reconciliation)

Significantly, in Isidingo it is the person of colour (Jack) who is asking forgiveness of a white person (Mariaan) in the ongoing struggle in the relationship between Mariaan and Jack. On the one hand, this reversal seems to lend support to critics of the show who attack it as being 'too white' (mainly by, about, and for white South Africans) - white viewers conveniently can see themselves as the aggrieved parties, with the burden being placed on South Africans of colour to heal racial rifts. ${ }^{7}$ This narrative can then be read as an obscene erasure of the material realities of South African history, and a denial of the systemic nature of power and discrimination. On the other hand, Isidingo's narrative here can be read as providing resistant South Africans of all races with a means of sympathising with the work of the TRC by reversing its presumed racial dynamics and so rendering its raison d'être to viewers at second remove - the political work of metaphor is again at work here. While viewers are not experiencing the TRC directly, their indirect engagement with its principles might create embodied connection to the TRC for them. In 
addition, the Mariaan/Jack narrative can be said to be complicating simplistic binaries, not only by recognising, as the TRC $\mathrm{did}^{8}$ that in addition to and despite the clear-cut injustices of apartheid, South Africans of all races were guilty of committing atrocities and indignities, and that to present all black South Africans as martyrs is as patronising as the demonisation of all black South Africans is racist, but also by interpolating a complicating discourse of gender into narratives of racial conflict and reconciliation. The personal relationship between Jack and Mariaan, relegated to the realm of the feminine in conventional patriarchal discourse, is here given equal weight to the masculinist public realm of 'politics', while Mariaan's complaint about Jack's infidelity becomes a feminist political contestation of patriarchal gender relations. The Jack/Mariaan narrative warns that gender and race do not necessarily fall along parallel axes of oppression and liberation, that racial reconciliation doesn't inevitably mean progress in the arena of gender relations (and vice versa), and that each axis of identity and power must be attended to both in their particular manifestations and in their intersections with, collisions with and inflections of each other.

\section{Post-apartheid?}

As I suggested earlier, in its displacement of racial stereotypes with gender stereotypes (Ana cleaning the house, Ana as hysteric), 102 Paradise Complex illustrates the difficulty of simultaneously tackling both racial and gender inequities for many political discourses and practices and for the cultural texts that are in some way shaped by these discourses and practices. The show's displacement of race onto gender is metonymised in the bonding of the four children along gender lines (the two girls stick together, and the two boys keep each other company; the credits at the beginning of the show group the two girls together and the two boys together, too) - this is a welcome rupture of the racial alliances associated with apartheid South Africa, but also retrieves equally problematic and essentialist conceptualisations of gender identity and identification. $^{9}$

Whereas 102 Paradise Complex can be read as unsettling racial fixity at the expense of reasserting gender stereotypes, Isidingo can be seen as having the more ambitious agenda of generating a sophisticated discourse about race in South Africa at the same time that it insists that race alone is an insufficient axis of identity around which to organise any liberation struggle. This insistence mirrors the ANC's commitment to gender equity and queer rights: as has been frequently noted both by progressive activists and politicians in South Africa and by outside commentators on the South African scene, the relatively late fruition of South Africa's civil rights struggle, together with its leaders' unusually high degree of intellectual achievements (a product partly of their education[s] and self-education[s] as activist-intellectuals in exile during apartheid) has given South African policymakers the benefit of hindsight (the failures of other liberation movements, including the US Civil Rights movement) and the insights of critical political analysis, so that they could avoid the pitfalls of single-issue social commitments. South Africa under the ANC was the first country in the world to enshrine lesbian and gay rights 
in its constitution, and Thabo Mbeki's second presidential inaugural address in 2004 was remarkable as much for his repeated references to gender equity as for its general intellectualism and political sophistication (it's impossible to imagine George Bush using the phrase 'non-sexist' in a speech as Mbeki did numerous times, let alone articulating feminist issues as a cornerstone of national policy). ${ }^{10}$ The integration of nonpathological gay characters into Isidingo is further evidence of the remarkable transformation of the country's mass media in the wake of apartheid's demise. ${ }^{11}$

This openness to nuanced, challenging and multivalent political discourse on the part of the ANC, the TRC, and artists and critics, far from presaging a capitulation to apartheid's apologists, underpins the courage and generosity of those who struggled against apartheid, and signals their political maturity. The evils of apartheid are a given; the challenge lies in the grey areas of more mundane politics. My generous reading of Isidingo, then, is as much an engagement with this politically sophisticated context as it is a commitment to the true multiculturalism - where culture doesn't just mean race - of the New South Africa. Any less generous reading of Isidingo would be reductive and complacent.

\section{Multilingual Discourses}

\section{Language in South Africa}

In this section, my desire to foreclose simplistic politics and binary conflicts moves to the arena of language in the soaps and sitcoms on South African television. Their deployment of various discourses of multilingualism, I argue, goes further than merely describing or even promoting 'truth and reconciliation' to actively enact this new political reality. I will demonstrate this thesis primarily with reference to a second subplot in Isidingo. Although this particular narrative seems to be quite separate from the Mariaan-Jack subplot discussed above, I want to argue that the two Isidingo subplots are essential complements to one another.

The post-apartheid South African constitution is unique in the world in many respects, not the least of which is its recognition of 11 official South African languages. ${ }^{12}$ Language in South Africa has a particularly political connotation. In the apartheid era, only English and Afrikaans, the most common languages spoken by white South Africans, were recognised as 'official' languages of South Africa. Historically, Afrikaans has predominantly been spoken by both white Afrikaners and 'coloured' South Africans (apartheid law classified all South Africans - often arbitrarily and illogically - into one of four racial categories: black, white, coloured and Asian). However, during the struggle against apartheid, Afrikaans was often seen as the language of the oppressor, and its mandatory use as a medium of instruction for black school children was one of the catalysts of the Soweto uprising of 1976. ${ }^{13}$ Given that the organs of apartheid South Africa, including statecontrolled TV, not only marginalised the languages spoken by black South Africans, but also undergirded apartheid by segregating the population in 
terms of both race and language, an embrace of multilingualism is today viewed in South Africa as a sign of progress away from the apartheid past.

The South African Broadcasting Corporation (SABC) has been assigned a pivotal role in the South African constitution's and government's explicit commitments to promoting all 11 official languages in its charge to broadcast in all the official languages and to promote previously marginalised languages. ${ }^{14}$ The SABC has taken up this charge in rewarding ways as it has reinvented itself to enact this imperative. In addition to broadcasting television programmes in different languages on the same channels in order to ensure that the channels don't foster linguistic segregation (Rooome, 1999: 313), the SABC (and other channel operators) have created many new television programmes that are themselves multilingual: often several presenters will anchor a single news programme or quiz show, each presenter speaking a different language (and thus representing and speaking to a different language constituency in South Africa); sometimes individual hosts will switch between two or three languages, often within the same sentence. Popular soap operas represent perhaps the apogee of this trend: different characters may speak different languages, individual characters may switch languages depending on whom they are addressing, or sometimes within sentences spoken to a single addressee, and dialogue is often subtitled into an additional language. Or, as is the case with the episode of 102 Paradise Complex discussed above in which several of the characters speak multiple languages, there may be no subtitles, an assumption of an already multilingual viewership or a viewership not loyal to conventional conceptions of understanding and mastery but resigned or accepting or delighting in the knowledge that understanding is always partial. And perhaps viewers come to terms with this partiality not as failure but as indicative of the richness of a multicultural society.

\section{Isidingo: Towards the new multiculturalism}

Not only, as illustrated in 102 Paradise Complex, and in other popular soap operas such as Generations, does current South African television programming enact a multilingualism designed to mirror the realities of a hybrid nation and move its peoples towards national reconciliation, but it also thematises language, as the issue of what language a character is speaking or how characters can deceive one another by speaking a particular language become central plot twists in locally produced soap operas and sitcoms. In Isidingo, the explicit conceptualisation of language as a political tool and a tool of politics is a reflection of both the long and formative history of language politics in South Africa and the new South African constitution's attention to linguistic equity.

This thematic is illustrated in one of the show's subplots in which Barker enlists Vusi's aid to persuade local community members to support Barker's efforts to exploit chromite on the site of a farm owned by Barker's son. Language becomes the source of power and conflict when Barker, the monolingual white entrepreneur, is temporarily tricked into believing that Vusi, the multilingual black mine geologist, is speaking on behalf of the monolingual black community members, when, in fact, Vusi is mistranslating 
the words of both the mine owner and the community members in order to serve his own ends. In a meeting between the black community members, arrayed on one side of a long table, and Barker and his white lawyer, sitting on the other side of the table, Vusi mistranslates the community members' rage at the prospect of a chromite mine being constructed on their ancestral graves in order to convince Barker that the community members support his plan and to reassure the community members that he is working in their best interest, and so to insinuate himself into the good graces of both sides in the dispute. English subtitles exacerbate the conflict by translating the community members' Setswana very differently from Vusi's oral translations into English.

On the one hand, this scene seems to enact a fairly conventional trope of the power of multilingualism, and the empowering potential of (mis)translation as a strategy to contest colonial/racist discourse: the colonised often know their masters intimately and inevitably understand their masters far better than their masters understand them. Thus, because Vusi is fluent in both Setswana and English, he is able to undermine the ambitions of the noncomprehending Barker, who must depend on Vusi's translations of the other men's words. But this is post-1994 South Africa, and so the binaries are not quite as black and white. For while Vusi is ostensibly working in the interests of the community members opposed to the proposed chromite mine, he is also misrepresenting Joseph Sekabe, the most vociferous opponent of Barker's plans, who is, apparently, equally as noncomprehending as Barker. Vusi, the multilingualist, is powerful because he understands everyone. He represents the pleasures of multilingualism. But he is not completely sympathetic, and can be read as a warning about how reactionary elements of a changing society might use multilingualism to entrench division, or even as a reactionary warning against the new South African multilingualism and the multiculturalism for which it stands.

On the other hand, the supposedly monolingual characters are inserted dynamically into the New South Africa in surprisingly rich and complicated ways. Joseph is clearly not as monolingual as Barker assumes, as he seems to understand Barker's English comments well enough to be able to respond with outrage to them in Setswana; inexplicably, though, he doesn't appear to realise that Vusi is mistranslating his outrage. The subtitles add another level of mediation, as any viewer's appreciation of the subtitles' relationship to the words they apparently translate is dependent both on that viewer's own multilingual literacies and reading literacy. Not unexpectedly, the white man, Barker, is the most monolingual of all the characters; yet even he participates in multiple acts of translation that suture him to the centre of the multilingual action. In the scene following the one described above, Barker's lawyer (the white man who sat silently next to Barker), tells Barker that he understands Setswana and explains that Vusi's translations are 'pure twaddle'. This narrative ends, then, with Barker's power, authority and knowledge reinforced, a trajectory that can be read in many ways (a reassertion of white authority in the wake of the demise of formal apartheid, the breakdown of old racial alliances implied by the white and black groupings on opposite ends of the table in the scene described above, an illustration of the various modes of functioning in a multilingual society, and so on). 
What I want to draw from these scenes is what they suggest about negotiating among various linguistic constituencies in a radically but unevenly multilingual culture like South Africa to argue, perversely perhaps, that they represent a nonidealised representation of successful multilingualism in action, process and transition. Although the scenes at first appear to demonstrate the problems of such an unevenness, they also show how different constituencies variously engage this context of inequity in ways that move beyond the expected, beyond appearances. Vusi understands everything but is still eventually 'understood' as well. Barker doesn't understand some of what is said in the meeting, but that does not matter because he is filled in later. His lawyer says nothing, but apparently understands most of what is said. Joseph speaks Setswana but clearly understands some English. Multilingual fluency is seldom complete, not surprisingly in a country with 11 official languages; it is unlikely that many people understand all of them, but communication does take place in a fragmented form that is nevertheless rich with possibility for a multicultural and increasingly hybridised society. This model of fragmentation does not fear multiplicating difference, doesn't posit reconciliation as dependent on homogeneity, and doesn't imagine incomprehension as a signal of miscommunication or a cultural and political gap to be filled. As microcosms of South Africa and the situations of different individuals and communities in multilingual contexts, Isidingo and other linguistically diverse television shows chart what Maingard (1997: 266) identifies as the un-singular and non-unitary identity and subjective experience of everyday life for many South Africans. Such an identity and its representation on television offers a counter to the postcolonial urge toward national and ethnic purity and the no less oppressive imperative from leftist cultural elites for linguistic authenticity and mastery.

The shows' audiences, meanwhile, build their linguistic repertoires, however fragmentedly, through their often unexpected (and even uninvited or hostile) engagement with the intersections, collisions, explanations and obfuscations of multiple languages dramatised on the shows - aided in no small way by the very allure of soap operas' melodramas and revelations as the invitation to all-knowing intimate knowledge about their all-too-real characters and plots.

Language(s), then, function(s) to demarcate identities as well as to destabilise those identities, much in the same ways that the plot lines in 102 Paradise Complex and Isidingo upset stereotypes - sometimes at the expense of recuperating other axes of power. In addition, language becomes proactive definer and creator of a new kind of multiculturalism in its deployments (reciprocally between viewers and television characters) as multi-, hybrid- and partial-signifier.

\section{Decolonising language?}

The multilingual focus of these and other television programmes reflects the realities and anxieties of a multilingual society, and also points to an exciting future where, with the withering away of formal apartheid, more and more South Africans will become even more hybrid and multilingual than 
they are already. The creation of a single truly South African multiculture is the dream of many South African nonracialists, though the uniformity and homogenisation that even such a bastardisation implies - because one multiculture suggests a sameness, even though the mark of that sameness is multiplicity - concerns those who fear for the loss of nuance and diversity previously found in the multiple individual cultures and languages. ${ }^{15}$ Moreover, the apparent and unsurprising hegemony of English can be seen as acceding to the coercive demands of imperialism and corporate globalisation rather than promoting a true democratic multilingualism ${ }^{16}$ : after all, while Setswana is sometimes subtitled into English on Isidingo, English is never subtitled into Setswana or isiZulu. The dominance of English on Isidingo could provide ammunition for the programme's detractors who see it as a 'white' show, ${ }^{17}$ or could at least cause concern for those who see decolonisation as necessarily connected with independence from European languages - in this case, English. Smitherman (2000: 331) makes the point that while the requirement that all South African schools teach each student at least two of the country's official languages (including, usually, each student's 'home' language) is laudable, because there is no requirement that one or both of these languages be a 'black' South African language, schools could just re-entrench the old order by teaching English and Afrikaans or could continue to privilege English by always having it as one of the two languages taught. ${ }^{18}$ As Smitherman (2000: 330) and Marback (2002: 356) also point out, one of the difficulties is that it is often black South Africans themselves who demand English instruction and instruction in English in South African public schools.

However, there are still several problems with Smitherman's apparently commonsense argument for requiring black South African languages in schools. First, today English and Afrikaans are spoken at home by fewer South Africans than was the case in 1996, indicating perhaps that the postapartheid political and cultural push for language equity has had some of its desired effect, and that English imperialism might not have diminished the speaking of other South African languages as much as might have been expected. Despite the increasingly cultural hegemony of English in South Africa, both Afrikaans and English were spoken at home by fewer South Africans in 2001 compared to 1996, according to the 2001 South African Census (South Africa grows, 2003). The most spoken home language, isiZulu, is spoken by less than one quarter of the South African population (South Africa grows, 2003), suggesting not only that the South African constitution's language policy is astute, given that there is no one dominant home language in South Africa, but also the substantial multiculturalism and multilingualism of South African society. Second, the contexts of colonialism and imperialism produce more reciprocal exchanges than a more comfortably binary schematic of power and domination might assume: the postcolonial experience suggests that English can no longer be spoken of solely as a white language, and in the context of South Africa, in particular, where the anti-apartheid liberation movements often used English politically as a unifying language to counter the apartheid government's attempts to divide black South Africans by exploiting ethnic and linguistic differences, English must be conceptualised as having multifaceted connotations. In his book of essays Decolonising the 
Mind, Kenyan writer Ngũgĩ wa Thiong'o (1986: xiv) vowed never again to write in English, the language of the coloniser. In parallel, dissident white Afrikaans South African poet-in-exile Breyten Breytenbach in 1983 stated his intention never again to write in Afrikaans (Roberts, 1986: 305), then considered the language of apartheid. Since then, Breytenbach has reneged on his promise, and Ngũgĩ has translated his newest works from Kikuyu into English, illustrating perhaps the short-sightedness of an argument that presumes language as fixed in its ownership, stable in its connotations and immune to hybridisations and appropriations of various kinds. The (ex-)coloniser's language becomes appropriated and reinvented by and integrated with the languages of the colonised; in the process, all the languages are transformed, as is the linguistic culture that determines their use and meaning. ${ }^{19}$

I am not, then, advocating multilingualism and multiculturalism in the service of an essentialism that seeks to reclaim, fix or idealise identity by reifying languages in the name of 'preserving cultures'. Marback (2002) sees a welcome counter to nationalism and ethnicism in language policy in South Africa as enabled and directed by the new South African constitution. As Marback (2002: 359) puts it, 'To assert the open limit of language rights, the South African constitution justifies itself to the people of the country through a set of founding values aimed at guiding them in their efforts to remedy current acts of discrimination, while leaving the way open for unforeseeable changes in language use.' This bifurcated vision recognises material linguistic history while at the same time refusing 'to insist on the legitimacy of certain languages solely on the basis of current language usage' (Marback, 2002: 358). ${ }^{20}$ Basing language policy solely on ethnic identification or current practice would contradict the agendas of invention and hybridity that impel current movements for multicultural nation-building in South Africa and would play into the hands of linguistic purists, nativists, ethnic nationalists and other fundamentalists in South Africa and elsewhere. I am advocating a dynamic and open-ended conceptualisation of multilingualism and multiculturalism that unyokes languages from proper names and radically disperses linguistic and national identifications. This would be part of the democratic project in a critical global context.

\section{Criss-crossing Stories}

Just as Mariaan's story interjects a feminist analysis into the rhetoric of truth and reconciliation, so the Mariaan/Jack subplot of Isidingo discussed above functions as an interrogative to the Vusi/Barker subplot. An intersecting tension between the past and the future, and between political discourse and its lagging material reality, is apparent in the arena of gender. At the same time that Jack and Mariaan are undergoing marriage counselling, Barker is working through multiple translations of his plan to replace ancestral graves with a chromite mine: the gendered and racialised narrative twist on the usual rhetoric of truth and reconciliation in South Africa (the Jack/Mariaan subplot) parallels the show's unpredictable treatment of multilingualism (the Vusi/ Barker subplot). In both cases, a reversal reinforces the known ('full disclosure' 
about apartheid South Africa) while also opening a space for the future unknown where identity is fluid and alliances are unpredictable - the marks of the multicultural new.

The subplots can also be seen as working metonymically in the sense that Jack and Mariaan's story is a feminist intervention into the Barker/Vusi narrative (the all-male racially divided scene around the table). In the same way that Mariaan's insistent returns to Jack's infidelity question his narrative of 'truth and reconciliation', the Mariaan/Jack subplot about gender relations acts as a critical counterpoint to the domain of all-male politics exemplified in the Vusi/Barker subplot (the women in Barker's and Vusi's lives and careers are relegated to the periphery of these scenes).

This is not to imply that Isidingo doesn't have problems in terms of gender (and other) representation: as I have already shown with 102 Paradise Complex, racial revolution sometimes comes at the expense of the recuperation of oppressive gender roles, suggesting (not unsurprisingly) the disjunctions between theory and practice that belie official commitments to gender equity in the New South Africa. In addition, it is unfortunate that Isidingo's feminist intervention comes in the form of a white woman (Mariaan), an intersection that does nothing to critique racist and imperialist gender stereotypes (where white women are freer legally and more liberated personally than women of colour) or ignorant (but common) insistences on feminism as white and Western. As Maingard (1997: 270) puts it in her otherwise complimentary analysis of Soweto: A History, a documentary series commissioned by the SABC in 1994, "The excesses of men as gangsters and rapists have been transformed into the excesses of men as liberators. Women as victims/ survivors, and women as co-liberators are effectively excluded.' The overlays of, and separations between, discourses of gender and race mark continuities across the ruptures of apartheid and its demise as well as the promise of discontinuity, with all the pleasures and dangers that are held by any discontinuity.

\section{Conclusion: The Old and the New}

Taking my cue from the soap operas and sitcoms I have been discussing, I'll stake out the master-narrative of my analyses by creating my own metaphor for the processes and possibilities of post-apartheid South African politics and culture. This metaphor came to me as I visited the South Africa Museum in Cape Town in 2003 and noticed some curious displays.

The curators of the South Africa Museum have responded to the first South African democratic election of 1994, community protests and critical ethnography by superimposing on each glass case display of 'traditional' African artefacts, peoples and practices a photograph or commentary chronicling a more contemporary and less stereotypical black South Africa. The rather rough intervention onto the original collection might originate as a function of a lack of funding and other resources, but the resulting jarring juxtaposition of Eurocentric anthropology with postcolonial intervention makes for a far more vivid historical and aesthetic commentary on South Africa and on museums than would any more cohesive narrative. 
In another section of the museum, the 'Bushman diorama' has been removed, following protests that its anthropological primitivism was racist. But the traces of its removal are very much still in evidence. The space where the old diorama used to be is still there, empty now, with a large sign guarding the entrance. The sign explains why the diorama has been removed. The sign and the empty diorama space themselves stand as exhibit in the museum now, rather than old business waiting to be cleaned up, and are greeted variously with resignation, dismay (that 'political correctness' has forced the closing of the 'beautiful and educational' diorama), and pleasure (that, finally, progressive voices and majority voices have had a say in the shaping of official South African culture) by museum goers. The process that led to the sign and the empty diorama space, as well as the continuing 'exhibition' of both, exemplifies both 'truth' and 'reconciliation' in their unglamorous roughness, and in their historicity and display of the materiality of power relations.

The overlaying of the new on the old, as with the Sangoma's embodiment in 102 Paradise Complex, the language intrigues in Isidingo, and the meetings of race and gender in both programmes substitutes for the more simplistic (and less robust) dynamic of replacement: here the marks of the old rupture and remind the new, as the new manifests its possibility as inevitably through the old; together they suggest uneasy coexistence as well as radical departure from more reductive paradigms of identity and change. Multilingualism and multiculturalism, too, cannot - should not - be seamless. These discourses of progress not only serve as a caution and model for diverse nationalisms worldwide, but also offer the (sometimes unwelcome) reassurance that history is never lost insofar as its traces become integral to transformative revolutionary praxis.

\section{Acknowledgements}

I am grateful to Rich Ruggiero and the Creative Media Department at California State University, Northridge for converting the South African video tapes to NTSC format for viewing in the USA, to the Inter-Library Loan staff at CSUN's Oviatt library for gathering materials for me so conscientiously, and to the Teachers for a New Era initiative at CSUN for a travel grant to present a much different earlier version of this paper at the 2004 Conference on College Composition and Communication. I also thank Iona Barnard, Barney Barnard, Barbara Kroll, Bob Cancel, Cathy Kroll and Aneil Rallin for assistance with this paper. Thanks, too, to the members of the English Department's Faculty Research Group at CSUN for their engaged and formative feedback on previous versions of the paper: Donald E. Hall, Beth Wightman, Michael Bryson, Ranita Chatterjee, Irene Clark, Leilani Hall, Scott Kleinman and Joseph T. Thomas, Jr. I am particularly grateful to Cezar Ornatowski, Shi-xu and the anonymous reviewers for Journal of Multicultural Discourses for their careful reading of and response to this essay. 


\section{Correspondence}

Any correspondence should be directed to Ian Barnard, Dept. of English, California State University Northridge, Northridge, CA 91330-8248, USA (ian.barnard@csun.edu).

\section{Notes}

1. For two concise discussions of the definition of Cultural Studies, see During (1993) and Nelson et al. (1992).

2. The Immorality Act also criminalised all gay sex, whether inter-racial or intraracial.

3. Kugel: popular cultural comic stereotype in South Africa of a middle- or upperclass English-speaking white/Jewish woman or girl with shallow liberal politics and a distinctive drawl.

4. I am using the term 'black' here to indicate all people of colour, consistent with the South African liberation movements' politicised use of the word to mark political positionality and resist the apartheid government's efforts to fracture the disenfranchised majority along ethnic and racial lines. 'Black' has also been used in this more general and political way in the UK, and elsewhere, though not in the USA (where, perhaps, the phrase 'people of colour' has a parallel political significance).

5. For an explanation of the TRC's principles, mission and decisions, as well as the statute that created it, see the TRC website: http://www.doj.gov.za/trc. Texts treating the TRC (both indirectly and directly) include Gobodo-Madikizela (2003), Krog (1999, 2000, 2003), Tutu (1999), and the films The Guguletu Seven (2000), Long Night's Journey Into Day (2000) and Ubuntu's Wounds (2002).

6. The specific events I am describing transpired on the show in 2002 and 2003. Since then, Mariaan and Jack have split up, and Jack and Vanessa have renewed their relationship - a turn of events that shows how difficult the achievement of South Africa's 'nonracial' future is, and that is paradigmatic of the way in which Isidingo chooses to focus on challenging political and personal problematics over facile idealism.

7. Several critics and others have lamented the fact that Isidingo has won so many major awards in South Africa, while Generations, another popular and multiracial evening soap opera, has not, attributing this disparity to the fact that Isidingo is 'whiter' than Generations, and as evidence of continued white dominance in South Africa (see Mokoena, 2001). Fan mail on Isidingo's website from viewers of all races suggests that this characterisation of the show might be reductive. See http:// www.isidingo.co.za (free registration required).

8. In South Africa there was much debate about and resistance to the TRC's final decision to hear testimony from victims of black violence as well as victims of white violence. This resistance came from disparate quarters, including segments of the Mandela government. For one account of the controversy, see Krog (1999). The film Long Night's Journey Into Day (2000) was similarly criticised for its attention to the case of Amy Biehl, a white US Fulbright scholar who was killed by a black man in South Africa.

9. For further discussion of this process of displacement in more theoretical terms, see Barnard (2004).

10. This isn't to say that South Africa is a paradise of gender equity. In 1999, for instance, only $38.1 \%$ of ministerial posts in South Africa and only $27.9 \%$ of parliamentary seats were occupied by women - a disappointing figure, but still significantly better than most other countries in the world (the corresponding figures for the USA, for example, are $31.8 \%$ and 13.8\%) (World Guide, 2003: 39). In addition, South Africa continues to generate notoriety for its high rape rate, though it is unclear whether this rate reflects an increase in the number of rapes or a fuller reporting of rapes. Nevertheless, public discourse in South Africa around gender issues, much of it coming from incumbent male politicians, is fairly unique in the world. 
11. As with gender, the politics of sexuality in South Africa has a complex history and present. While the apartheid South African government did criminalise homosexual sex, it also in some ways allowed its racism to override its homophobia in its appeals to racist white gay voters. And while the ANC governments and the judiciary in the new South Africa have made unprecedented efforts to protect queer rights, many commentators have argued that the ANC rank and file, and average South Africans, are as homophobic as ever. For further discussion of homophobia in the old and new South Africas, see Chapter 2 of Barnard (2004) and Gevisser and Cameron (1994).

12. For information about constitutional provisions regarding language in postapartheid South Africa, see Smitherman (2000). For an insightful comparison of language policy in South Africa and the USA, see Marback (2002).

13. For further discussion of the politics of Afrikaans, see Barnard (1992).

14. For discussions of the history and current political mission of the SABC and other television broadcasters in South Africa, see Currie and Markovitz (1993), Dodge (1996), Maingard (1997) and Rooome (1999).

15. See Sparks (2003: 145) for a discussion of language in the context of Afrikaner identity, and the concern about loss of language purity in the new South Africa.

16. See Dalby (2003) for a discussion of the politics of English in the context of Western imperialism, transnational corporate capitalism and the worldwide loss of linguistic diversity.

17. See note 7 .

18. For general discussion of language policy in South African public education, see Heugh et al. (1995).

19. Translation also impacts multilingualism in that translations between languages shape the meanings in and of both languages and both cultures with which the languages are affiliated. Krog (2003) makes this point brilliantly in her genrebending and multilingual A Change of Tongue. In Part 4 of this text, 'A Translation', Krog addresses issues around translation and explains how the Afrikaans language itself was transformed when Nelson Mandela's autobiography was translated into Afrikaans (by Krog). For an exemplary discussion of the ways in which (mis)translation can be used as countercolonial activism, see Rafael (1988). For a discussion of the complexities of language in postcolonial and transnational contexts, see Spivak (1990).

20. My own (and Marback's) anti-essentialist insistence can be counterposed with, for instance, the recent work of Canagarajah (2004), who, I would argue, envisages linguistic diversity as a matter of validating particular communities.

\section{References}

Amandla!: A Revolution in Four-Part Harmony (Film) (2002) L. Hirsch (Dir.). South Africa/USA: Kwela Productions.

Ansell, G. (2004) Soweto Blues: Jazz, Popular Music, and Politics in South Africa. New York: Continuum.

Barnard, I. (1992) The 'Tagtigers'?: The (un)politics of language in the 'new' Afrikaans fiction. Research in African Literatures 23 (4), 77-95.

Barnard, I. (2004) Queer Race: Cultural Interventions in the Racial Politics of Queer Theory. New York: Lang.

Canagarajah, S. (2004) Presentation for panel on cross-language relations in composition. Conference on College Composition and Communication, San Antonio.

Currie, W. and Markovitz, M. (1993) The people shall broadcast: The struggle for a postapartheid national television culture in South Africa. In T. Dowmunt (ed.) Channels of Resistance: Global Television and Local Empowerment (pp. 90-105). London: British Film Institute.

Dalby, A. (2003) Language in Danger: The Loss of Linguistic Diversity and the Threat to Our Future. New York: Columbia University Press. 
David, S.M. (2001) Popular culture in South Africa: The limits of black identity in 'Drum' magazine. PhD dissertation, University of Illinois at Urbana-Champaign.

Dodge, H. (1996) The role of South African television as an agent of 'truth and reconciliation'. South African Theatre Journal 10 (2), 148-154.

During, S. (1993) Introduction. In S. During (ed.) The Cultural Studies Reader (pp. 1-25). New York: Routledge.

Editorial statement. Cultural Studies web site. On WWW at http://www.unc.edu/ depts/cultstud/journal/statement.htm. Accessed 22.10.05.

Erb, C. (2000) King Kong in Johannesburg: Popular theatre and political protest in 1950s South Africa. In X. Chen and C. Sponsler (eds) East of West: Cross-Cultural Performance and the Staging of Difference (pp. 143-165). New York: Palgrave.

Flockemann, M. (2000) Watching soap opera. In S. Nuttall and C. Michael (eds) Senses of Culture: South African Culture Studies (pp. 141-154). Cape Town: Oxford University Press.

Gevisser, M. and Cameron, E. (eds) (1994) Defiant Desire: Gay and Lesbian Lives in South Africa. Johannesburg: Raven.

Gobodo-Madikizela, P. (2003) A Human Being Died That Night: A South African Story of Forgiveness. Boston, MA: Houghton Mifflin.

Guguletu Seven, The (Film) (2000) L. Wilson (Dir.). South Africa/UK.

Hebdige, D. (1979) Subculture: The Meaning of Style. London: Methuen.

Heugh, K., Siegrühn, A. and Plüddemann, P. (eds) (1995) Multilingual Education for South Africa. Johannesburg (Isando): Heinemann.

hooks, b. (1994) Introduction: The heartbeat of cultural revolution. In b. hooks Outlaw Culture: Resisting Representations (pp. 1-7). New York: Routledge.

Horn, A. (1986) South African theatre: Ideology and rebellion. Research in African Literatures 17 (2), 211-233.

Isidingo (December 2002-January 2003) G. Schoonhoven, R. Gorlei, K. Smith and R. Sargeant (Dir.). Executive Head Writer: M. Booysen. Executive Producer: G. Hofmeyr. SABC 3.

Isidingo (December 2002-January 2003) Episode directed by G. Schoonhoven. Written by C. Stopford. SABC 3.

Isidingo web site. On WWW at http://www.isidingo.co.za. Accessed 2.8.04.

Krog, A. $(1999,2000)$ Country of My Skull: Guilt, Sorrow, and the Limits of Forgiveness in the New South Africa. New York: Three Rivers.

Krog, A. (2000) Kleur Kom Nooit Alleen Nie. Roggebaai, South Africa: Kwela.

Krog, A. (2003) A Change of Tongue. Johannesburg: Random.

Lewis, D. (2000) Prized pleasures: T.V. game shows. In S. Nuttall and C. Michael (eds) Senses of Culture: South African Culture Studies (pp. 155-177). Cape Town: Oxford University Press.

Long Night's Journey Into Day (Film) (2000) D. Hoffmann and F. Reid (Dir.). USA: Seventh Art Releasing.

Maingard, J. (1997) Transforming television broadcasting in a democratic South Africa. Screen 38 (3), 260-274.

Marback, R. (2002) Language rights in South Africa: Lessons for the United States. jac $22(2), 355-375$.

Mokoena, E. (16 July 2001) Race row hits TV awards. Online database. Africa News Service: 1008197u2361. Expanded Academic ASAP [1 May 2003].

Nelson, C., Treichler, P.A. and Grossberg, L. (1992) Cultural studies: An introduction. In C. Nelson, P.A. Treichler and L. Grossberg (eds) Cultural Studies (pp. 1-16). New York: Routledge.

Ngũgĩ wa Thiong'o (1986) Decolonising the Mind: The Politics of Language in African Literature. London: James Currey.

102 Paradise Complex (Bat outta hell episode) (2003) Writer: M. Bekker. Dir. B. Cawood. Prod. M.S. Phillips. Baena Productions: SABC 2.

Radway, J.A. (1984) Reading the Romance: Women, Patriarchy, and Popular Literature. Chapel Hill, NC: University of North Carolina Press. 
Rafael, V.L. $(1988,1993)$ Contracting Colonialism: Translation and Christian Conversion in Tagalog Society Under Early Spanish Rule. Durham, NC: Duke University Press.

Register of reconciliation. On WWW at http://www.doj.gov.za/trc/ror/index.htm. Accessed 31.7.04.

Roberts, S. (1986) Breyten Breytenbach's prison literature. Centennial Review 30, 304-313.

Rooome, D.M. (1999) Global versus local: 'Audience-as-public' in South African situation comedy. International Journal of Cultural Studies 2 (3), 307-328.

Smitherman, G. (2000) Language and democracy in the USA and the RSA. In G. Smitherman Talkin that Talk: Language, Culture, and Education in African America (pp. 314-333). New York: Routledge.

South Africa grows to 44.8 million (9 July 2003) SouthAfrica.info: The Official Gateway. On WWW at http://www.safrica.info. Accessed 22.2.04.

Sparks, A. (2003) Beyond the Miracle: Inside the New South Africa. Johannesburg: Jonathan Ball.

Spivak, G. (1990) Postmarked Calcutta, India. Interview by Angela Ingram. In S. Harasym (ed.) The Post-Colonial Critic: Interviews, Strategies, Dialogues (pp. 75-94). New York: Routledge.

Steadman, I. (1984) Alternative politics, alternative performance: 1976 and black South African theatre. In M.J. Daymond, J.U. Jacobs and M. Lenta (eds) Momentum: On Recent South African Writing (pp. 215-232). Pietermaritzburg: University of Natal Press.

Steadman, I. (1986) Popular Culture and Performance in South Africa. Pietermaritzburg: Contemporary Cultural Studies Unit, University of Natal.

Steadman, I. (1988) Stages in the revolution: Black South African theater since 1976. Research in African Literatures 19 (1), 24-33.

Truth and Reconciliation Commission website (2001) On WWW at http://www.doj. gov.za/trc. Accessed 2.8.04.

Tutu, D. (1999) No Future Without Forgiveness. New York: Doubleday.

Ubuntu's Wounds (Film) (2002) S. Morojele (Dir.). South Africa/USA: Home Box Office.

Wood, R. (1986) Hollywood From Vietnam to Reagan. New York: Columbia UP.

World Guide, The: An Alternative Reference to the Countries of Our Planet: 2003-2004 Edition (2003) New Internationalist: Oxford.

Ian Barnard grew up in Johannesburg, earning a BA Honours in English at Wits University. He received his PhD from the University of California, San Diego, and is currently Assistant Professor English and Teachers for a New Era faculty at California State University, Northridge. His research and teaching interests include composition, critical theory, African literatures, cultural studies and teacher preparation. His papers and reviews on South African culture and politics have appeared in Z Magazine, Research in African Literatures and African Arts. He has also published the book Queer Race: Cultural Interventions in the Racial Politics of Queer Theory. 